\title{
"Regions Remote from Revolutionary Scenes": Regionalism, Nationalism, and the Iowa Daughters of the American Revolution, 1890-1930
}

\author{
FRANCESCA MORGAN
}

AT THE 1903 IOWA STATE CONFERENCE of the Daughters of the American Revolution (DAR), state regent Maria Purdy Peck expressed "many misgivings" about the DAR's future growth in Iowa. Because historical sites and artifacts pertinent to the nation's birth were rare "in regions remote from Revolutionary scenes," she observed, "the general interest is not as keen ... a as in localities where memories of our grand, heroic past have never been permitted to grow dim." The next year, in 1904, Iowa state historian Sophia Hyndshaw Bushnell echoed Peck's conviction that the relative dearth of Revolutionary sites and artifacts in Iowa, apart from the graves of Revolutionary veterans who had migrated there in the nineteenth century, left Iowa DAR members with little to do. "We of the middle west so far from the battlefields of the Revolution and its environments," Bushnell wrote, "must strive to keep alive our patriotism, by

A grant in 1994-95 from the State Historical Society of Iowa, funded by the Iowa Sesquicentennial Commission, made this article possible. I would also like to thank Marvin Bergman and Bridgett Williams-Searle of the Annals of Iowa, the archivists at the State Historical Society of Iowa in Iowa City, Elizabeth S. Blackmar, Elizabeth Toon, and the two anonymous readers for the Annals of Iowa who commented on this manuscript.

THE ANNALS OF IOWA 56 (Winter/Spring 1997). CThe State Historical Society of Iowa, 1997. 
keeping in close touch ... with our more favored sisters of the east and to catch from them and their work, the enthusiasm and inspiration that comes of a history than which there is none more creditable or more glorious."

Founded in Washington in 1890, the National Society of the Daughters of the American Revolution (NSDAR), an ancestral organization of white Revolutionary soldiers' female descendants, was immediately successful in organizing chapters in the Northeast. ${ }^{2}$ Because of the perceived urgency of preserving houses and landmarks of Revolutionary significance in rapidly industrializing urban areas, the DAR burgeoned in Connecticut, New York, and Pennsylvania. West of the Appalachians, DAR members before 1900 had no such ready source of projects. Yet by World War I, the DAR had organized local chapters in every American state and territory, as well as in Cuba and the Philippines, and boasted more than one hundred thousand members. After 1904, Iowa alternated with Ohio as the largest DAR organization in the Midwest (see table 1).

1. Maria Purdy Peck, "State Regent's Report," in Iowa Daughters of the American Revolution (hereafter cited as Iowa DAR), Fourth Annual Conference 4 (1903), 6; Sophia H. Bushnell, "State Historian's Annual Report," Iowa DAR, Fifth Annual Conference 5 (1904), 20.

2. See Wallace Evans Davies, Patriotism on Parade: The Story of Veterans' and Hereditary Organizations in America, 1783-1900 (Cambridge, MA, 1955); and Lucile Evelyn LaGanke, "The National Society of the Daughters of the American Revolution: Its History, Policies, and Influence, 1890-1949" (Ph.D. diss., Case Western Reserve University, 1951); Stuart McConnell, "Reading the Flag: A Reconsideration of the Patriotic Cults of the 1890s," in Bonds of Affection: Americans Define Their Patriotism, ed. John Bodnar (Princeton, NJ, 1996), 102-19; and Cecilia Elizabeth O'Leary, "Patriotic Culture: The Politics of National Identity in the United States, 1865-1918" (Ph.D. diss., University of California at Berkeley, 1995), 91-141. Nonacademic histories of the DAR include Peggy Anderson, The Daughters: An Unconventional Look at America's Fan Club-The D.A.R. (New York, 1974); Margaret Gibbs, The DAR (New York, 1969); and Martha Strayer, The Daughters of the American Revolution: An Informal History (Washington, DC, 1958). The NSDAR has itself produced numerous internal histories of the organization; the most recent is Ann Arnold Hunter, A Century of Service: The Story of the DAR (Washington, DC, 1991). On the modern DAR, see Barbara Truesdell, "God, Home, and Country: Folklore, Patriotism, and the Politics of Culture in the Daughters of the American Revolution" (Ph.D. diss., Indiana University, 1996). 
TABLE 1

NUMBERS OF DAR CHAPTERS IN MIDWESTERN STATES

\begin{tabular}{|c|c|c|c|c|c|c|c|c|c|c|}
\hline Year & IA & IL & IN & $\mathrm{OH}$ & MI & MN & $\mathrm{NE}$ & KS & $\mathrm{MO}$ & $\begin{array}{l}\text { Nationwide } \\
\text { (NSDAR) }\end{array}$ \\
\hline 1896 & 4 & 12 & 2 & 16 & 1 & 5 & $\mathrm{n} / \mathrm{a}$ & $\mathrm{n} / \mathrm{a}$ & 2 & 230 \\
\hline 1904 & 26 & 32 & 16 & 36 & 17 & 14 & 6 & 4 & 11 & 687 \\
\hline 1912 & 53 & 44 & 50 & 50 & 36 & 18 & 19 & 20 & 39 & 1,187 \\
\hline 1922 & 86 & 77 & $\mathrm{n} / \mathrm{a}$ & 76 & 58 & 26 & 40 & 29 & $\mathrm{n} / \mathrm{a}$ & 1,847 \\
\hline 1928 & 105 & 104 & 83 & 106 & 60 & 51 & 49 & 39 & 85 & 2,290 \\
\hline
\end{tabular}

SOURCES: "Proceedings of the Fifth Continental Congress," American Monthly Magazine 8 (1896), 452-68; "Proceedings of the Thirteenth Continental Congress," American Monthly Magazine 25 (1904), 69, 99-165; Daughters of the American Revolution, Proceedings of the Continental Congress 21 (1912), 6, 34, 602-675; ibid. 31 (1922), 35, 361-65; Daughters of the American Reoolution Magazine 62 (1928), 510; Daughters of the American Revolution, Proceedings of the Continental Congress 37 (1928), 19, 34, 61.

How did the DAR thrive after 1900 in a state with no Revolutionary War landmarks apart from its veterans' graves? The answer lies in the DAR's array of projects, which ranged far beyond studying and commemorating the American Revolution. Starting in 1903, DAR members redefined their historical projects in ways that appealed to the upper middle-class pillars of Iowa cities and towns. Moving beyond their original focus on colonial and Revolutionary history, the women of the DAR came to view the history of America's nineteenth-century westward expansion as a continuation of the history of the nation's birth. Thus the DAR developed a flexible nationalism that accommodated regional diversity. DAR activities also came to encompass nonhistorical projects that did not require the presence of Revolutionary landmarks. These projects likewise were pursued under the rubric of nationalism and patriotism. Despite its reputation for nativism and red-baiting, the DAR in Iowa was a progressive organization before the mid-1920s. Its members worked on their own (notably in settlement houses) and promoted government intervention to ameliorate social problems such as child labor and infant mortality. Iowa DAR members also worked among new immigrants from Europe and Latin America, teaching them English, American history, and civics in the hopes of promoting their assimilation and making them 
citizens. ${ }^{3}$ After 1925, however, many DAR members in Iowa and elsewhere turned against reformist causes. They decided that domestic radicalism posed a greater threat to the nation's children than did unregulated capitalism, and that an activist federal government smacked of Soviet-style central planning. Disseminating materials generated by the antiradical right, DAR members embarked on an extensive program of countersubversion. Even after the DAR's antiradical and antireformist zeal began to make it controversial, however, DAR membership continued to attract Iowa women because it conferred social prestige on the community level.

EXAMINING WHY the DAR attracted Iowa women requires an investigation of what kind of Iowa woman joined it. ${ }^{4}$ Iowa

3. For settlement house work by DAR members elsewhere in the Midwest (notably in Detroit and in cities in Ohio), see Huldah L. Richards, Minutes, Second Annual State Conference of Chapters, 23 May 1902; Bertha Black, Minutes, Fourth Annual State Conference, 20 May 1904; Proceedings of the State Conference, vol. 1 (1900-1914), 23, 32, 41, box 3, Papers of the Daughters of the American Revolution, Michigan Society, Michigan Historical Collections, Bentley Library, University of Michigan, Ann Arbor; Irene W. Chittenden, Michigan State Regent, Report, "Annual Report of State Regents," American Monthly Magazine 24 (1904), 679-80; Reports of Canton [Ohio] Chapter DAR; Fort Industry Chapter DAR (Toledo, Ohio); and Jonathan Dayton Chapter DAR (Dayton, Ohio), all in NSDAR Americanization Committee Reports of Chapter Regents to State Regent, 1920, Western Reserve Historical Society, Cleveland, Ohio.

4. Newspaper clippings and other materials in scrapbooks compiled by DAR state and chapter regents contain extensive biographical data on the Iowa DAR's first generation. These scrapbooks now constitute part of Daughters of the American Revolution Collection at the State Historical Society of Iowa, Iowa City (hereafter cited as DAR Collection). I have collected and analyzed obituaries, fiftieth-anniversary notices, and printed and typewritten DAR tributes pertaining to 301 Iowa DAR members born before 1900. Except for the tributes written by other DAR members, most of these materials appeared originally in local newspapers as obituaries. The clippings were found in scrapbooks compiled by DAR state historians, scrapbooks known as "necrology rolls" compiled by DAR state chaplains, and scrapbooks compiled by chapter members in Jefferson and Newton. Of the 301 obituaries and other notices examined, 133 were found in the State Chaplain's Record/Necrology Rolls Scrapbook, vol. 1, 1903-1948; 105 in the State Chaplain's Record/Necrology Rolls Scrapbook, vol. 2, 1948-1957; 28 in the Iowa Society DAR Scrapbook (Historian's Book), vol. 3, 1942-1943; 7 in the Iowa Society DAR Scrapbook (Historian's Book), vol. 4, 1944-1945, all in box 2; 18 in the Independence Chapter (Jefferson, Iowa) DAR Scrapbook, 1911-1961, box 6; 3 in Isham Randolph 
DAR members' educational attainments, Protestant religion, small families, membership in specific other clubs, and their husbands' and male relatives' occupations locate most of them in America's upper middle class. Within Iowa and their own communities, most occupied the upper tiers of what Catherine McNicol Stock, in her study of Dakota towns in the Great Depression, called the "old middle class" of independent proprietors. ${ }^{5}$ Iowa DAR members married businessmen (frequently business owners or executives), politicians, and professionals, particularly physicians and attorneys. Those employed outside their homes taught school, worked in offices and libraries, and ran their own businesses.

My sample of 301 Iowa DAR members encompasses more than one generation. Some members had been born in the Northeast in the 1820s and 1830s to Revolutionary veterans (Sophia Dolson Andrews's father crossed the Delaware with George Washington). ${ }^{6}$ Others, born in the 1890 s, were the granddaughters of Iowa homesteaders. Most of the Iowa DAR members in the sample ( 84.2 percent) had been born in Iowa or the upper Midwest. ${ }^{7}$ The vast majority ( 88.1 percent) of them were married

Chapter (Newton, Iowa) DAR Historian's Book, 1917-1937, box 12; 1 in the Pilgrim Chapter (Iowa City) DAR miscellaneous records, box 9. Two more obituaries in this sample were printed in Iowa DAR, Fifteenth Annual Conference 15 (1914), and 4 more were printed in Iowa DAR, Twentieth Annual Conference 20 (1919). Copies in the library of the State Historical Society of Iowa, Iowa City. These sources are not without problems. The comprehensiveness of an obituary tends to reflect its subject's social prominence. This is particularly true of the newspaper obituaries that account for the vast majority of this sample.

5. Catherine McNicol Stock, Main Street in Crisis: The Great Depression and the Old Middle Class on the Northern Plains (Chapel Hill, NC, 1992), 2, 7, 11, 13, 47.

6. "Real Daughter of Revolution Died at Noon," 4 December 1924, and "Mrs. Andrews Was Pioneer," n.d. [1924], otherwise unidentified clippings, Iowa Society DAR Scrapbook (Historian's Book), vol. 1, 1911-1934, comp. Sarah Paine Hoffmann, box 3, DAR Collection.

7. More than half of these women (141, or 53 percent of the 266 obituaries listing birthplaces) had been born in Iowa; 83 others, or 31.2 percent, had been born elsewhere in the Midwest, the majority of these east of the Mississippi. Of the rest, 18 (6.8 percent) had been born in the mid-Atlantic states of New York and Pennsylvania, 17 (6.4 percent) in New England, and 3 (1.1 percent) in the West. Only 4 (1.5 percent) in this sample were southern-born; of these, one was born in the border state of West Virginia. 
TABLE 2

DAR MEMBERS' AGES AT FIRST MARRIAGE ( $\mathrm{N}=162)$

\begin{tabular}{lrc}
\hline Age & $\mathrm{N}$ & $\%$ \\
\hline $16-19$ & 22 & 13.6 \\
$20-24$ & 79 & 48.8 \\
$25-29$ & 37 & 22.8 \\
$30-39$ & 19 & 11.7 \\
$40-49$ & 5 & 3.1 \\
\cline { 2 - 3 }$\quad$ Total & 162 & 100.0 \\
\hline
\end{tabular}

SOURCES: See note 4.

or widowed; 11.9 percent remained single for their entire lives. The married DAR members had not wed until they reached an average age of 24.8 years (see table 2 ). ${ }^{8}$ They also bore an average of 2.28 children, a relatively small number (the national average was 3.56 in 1900). Indeed, a high 15.6 percent of this sample were apparently childless (compared to a national rate of 9.6 percent in 1910). ${ }^{9}$ Having few or no children to raise left these women the spare time necessary to participate in the DAR's activities (see table 3).

The obituaries also reveal that DAR chapters in Iowa were an urban and town phenomenon, as were many early twentiethcentury women's associations. Attending daytime meetings and sitting on committees required leisure time that many rural women lacked. Only ten DAR members in this sample, or 3.3

8. Compared to Iowa women in general, as measured by the 1905 Iowa state census, a comparatively high number of DAR women never married. On the other hand, Iowa DAR women who did marry tended to do so at an earlier age than Iowa women in general. In the counties of Black Hawk, Dubuque, Ida, Johnson (containing Iowa City), Polk (containing Des Moines), Pottawattamie (containing Council Bluffs), and Wapello (containing Ottumwa) in 1905, the average percentage of women over the age of 45 who had never married was 5.2 , compared to DAR members' 11.9 percent. In the same counties, an average of only 5.2 percent of women under the age of twenty-one were married, compared to DAR members' 13.6 percent. Census of Iowa for 1905, 474-81, 486-89, 558-83.

9. The national rate of childlessness among white women in their late forties rose to 16.5 percent by 1940. U.S. Department of Commerce, Census Bureau, Historical Statistics of the United States, Colonial Times to 1970, Part 1 (Washington, DC, 1975), 44. See also Linda Gordon, Woman's Body, Woman's Right: Birth Control in America, rev. ed. (New York, 1990), 150. 
TABLE 3

NUMBERS OF CHILDREN OF DAR MEMBERS $(\mathrm{N}=225)$

\begin{tabular}{lrc}
\hline Number of children & $\mathrm{N}$ & $\%$ \\
\hline No children & 35 & 15.6 \\
1 child & 53 & 23.5 \\
2 children & 52 & 23.1 \\
3 children & 40 & 17.8 \\
$4-5$ children & 36 & 16.0 \\
6 or more children & 9 & 4.0 \\
\cline { 2 - 3 }$\quad$ Total & 225 & 100.0 \\
\hline
\end{tabular}

SOURCES: See note 4.

NOTES: The number of children includes adopted children, foster children, stepchildren, and children who died in infancy or childhood. It is possible that some of the women who appeared to be childless had children who predeceased them and were not listed in their obituaries.

percent, lived on farms all their lives. ${ }^{10}$ The rest were townspeople.

Most DAR members' educational attainments place them and their immediate families within the upper middle class. Almost all of the women in this sample had finished high school, and over two-thirds had attended or graduated from college (see table 4).

Another indication that most Iowa DAR members belonged to the upper middle class was their membership in other socially prestigious associations. A total of 62.4 percent of those members whose club affiliations are known belonged to sororal organizations and lodges such as the Order of the Eastern Star and the P.E.O. Sisterhood. ${ }^{11}$ Living in a predominantly Republican state

10. This number includes a woman whose obituary identified her husband as both a farmer and a merchant. Many more DAR members had spent their childhoods on farms, and twenty-seven (9 percent) lived on farms for part of their adult lives.

11. Two hundred thirty-seven obituaries (78.7 percent of the entire sample) list their subjects' club affiliations other than their DAR memberships (these include church activities and membership on library and hospital boards). Seventy-nine of these ( 33 percent) reported belonging to the Order of the Eastern Star; 37 (15.6 percent) to the P.E.O. Sisterhood; 13 (5.5 percent) to the Order of the White Shrine of Jerusalem; 10 (4.2 percent) to the Rebekah Lodge; 5 to the Pythian Sisters; 2 to the Elklets; 2 to the Lionelles; and 1 to the Kiwanis Kweens. 
TABLE 4

EDUCATIONAL ATTAINMENTS OF DAR MEMBERS $\left(\mathrm{N}=116^{\mathrm{a}}\right)$

\begin{tabular}{lrc}
\hline Educational level & $\mathrm{N}$ & $\%$ \\
\hline Completed high school $^{\mathrm{b}}$ & 17 & 14.7 \\
Some college $^{\mathrm{b}}$ & 37 & 31.9 \\
Completed college & 53 & 45.7 \\
Some postgraduate education & 2 & 1.7 \\
Completed graduate school & 7 & 6.0 \\
\cline { 2 - 3 }$\quad$ Total & 116 & 100.0 \\
\hline
\end{tabular}

SOURCES: See note 4.

"Eighteen additional obituaries in this sample gave no educational information but reported that members had taught school, indicating at least a high school education. The Iowa DAR members in this sample were comparatively well educated. In 1880 only 2,485 women nationwide (compared to 10,411 men) had received bachelor's or "first professional" degrees: that number rose to 2,682 in $1890,5,237$ in 1900 , and 8,437 in 1910. As late as 1940, women who had attended or graduated from college made up only 10.4 percent of the female population. Historical Statistics of the United States, 380, 386.

'This number includes those DAR members who attended or completed business courses, "seminaries," and "academies."

with a strong cultural identification with New England, 10.5 percent of them belonged to auxiliaries of Union veterans' organizations such as the Daughters of Union Veterans and the Woman's Relief Corps. ${ }^{12}$ More than a quarter of the sample also belonged to local women's clubs affiliated with national umbrella organizations such as the General Federation of Women's Clubs. ${ }^{13} \mathrm{~A}$

12. None reported belonging to the United Daughters of the Confederacy or to other Confederate veterans' organizations. Of the 237 obituaries reporting club affiliations, a total of 25 (10.5 percent) reported belonging to Civil War veterans' organizations: 13 to the Woman's Relief Corps, 5 to the Daughters of Union Veterans, and 7 to the Grand Army of the Republic (GAR) or to the Ladies of the GAR.

13. Of the 237 obituaries reporting club affiliations, 66 ( 27.8 percent) reported belonging to their local city or town woman's club and/or to the Iowa Federation of Women's Clubs; 17 more (7.2 percent) reported belonging to literary clubs or Chautauqua circles; 9 reported belonging to garden clubs, 4 to music clubs, and 3 to Shakespearean clubs. For discussions of women's associational life in Iowa towns, see Thomas J. Morain, Prairie Grass Roots: An Iowa Small Town in the Early Twentieth Century (Ames, 1988), 88-108; and Christine Pawley, "'Not Wholly Self Culture': The Shakespearean Women's Club, Osage, Iowa, 1892-1920," in this issue. 
TABLE 5

DAR MEMBERS' RELIGIOUS AFFILIATIONS ( $\mathrm{N}=218)$

\begin{tabular}{lrr}
\hline Denomination & $\mathrm{N}$ & $\%$ \\
\hline Methodist & 80 & 36.7 \\
Presbyterian & 47 & 21.6 \\
Congregationalist & 46 & 21.1 \\
Episcopal & 18 & 8.3 \\
Baptist & 12 & 5.5 \\
Disciples of Christ & 8 & 3.7 \\
Other $^{3}$ & 7 & 3.2 \\
\cline { 2 - 3 }$\quad$ Total & 218 & 100.1 \\
\hline
\end{tabular}

SOURCES: See note 4.

"This number includes 3 Christian Scientists, 2 Unitarians, 1 Universalist, and 1 Roman Catholic.

small number also engaged in temperance and suffrage work. ${ }^{14}$ Iowa DAR members were a religious group: 72.4 percent of the women in the overall sample gave information on their church affiliations. They belonged to mainstream Protestant denominations, with a preponderance (73.9 percent) of Methodists, Presbyterians, and Congregationalists (see table 5).

DAR members' occupations, the occupations of their fathers and husbands, and their families' social prominence indicate that the townswomen who joined the DAR in Iowa belonged to the upper middle class. In addition to the unpaid work done by most middle-class women within the home, ranging from child raising to housework to caring for elderly parents, 129 women in this sample ( 43 percent) performed paid labor outside the home. Most of these women were single or widowed: middle-class married women at the time were rarely employed outside the home, although a physician, a nurse, a beauty shop

14. Twelve DAR members in this sample (5.1 percent) belonged to the Woman's Christian Temperance Union (two were presidents of their local unions). Six members ( 2.5 percent) were either described as suffragists or belonged to local suffragist clubs. No one in this sample reported belonging to antisuffrage organizations. After World War I, two members were active in the League of Women Voters. Thirteen others (10 Republicans and 3 Democrats) were active in county and state party politics, though none held office. On women's activism in party politics in Iowa after suffrage, see Catherine E. Rymph, "'Keeping the Political Fires Burning': Republican Women's Clubs and Female Political Culture in Small-Town Iowa, 1928-1938," in this issue. 
TABLE 6

DAR MEMBERS' OCCUPATIONS ( $\mathrm{N}=129)$

\begin{tabular}{lrr}
\hline Occupation & $\mathrm{N}$ & $\%$ \\
\hline Educators $^{\mathrm{a}}$ & 78 & 60.5 \\
Clerical workers $^{\mathrm{b}}$ & 12 & 9.3 \\
Business owners $_{\text {Authors }}$ & 7 & 5.4 \\
Local officeholders $^{\text {Journalists }}$ & 7 & 5.4 \\
Medicine $^{\mathrm{c}}$ & 6 & 4.7 \\
Other $^{\mathrm{d}}$ & 5 & 3.9 \\
$\quad{ }^{\text {Total }}$ & 4 & 3.1 \\
\cline { 2 - 3 } & 10 & 7.8 \\
\hline
\end{tabular}

\section{SOURCES: See note 4.}

"Includes 63 primary and secondary school teachers (48.1 percent), 11 college instructors or professors (8.4 percent), and 4 educational administrators ( 3.1 percent).

'Includes various types of office workers, including bookkeepers. 'Includes 3 practicing nurses and 1 physician, Alice Hatch of Des Moines. 'Includes 3 members who wrote or edited newspapers' society pages, 3 librarians (this number does not include the many DAR members who engaged in library work on a volunteer basis), 2 school board members, and 1 professional singer.

owner, the Spirit Lake postmistress, and a teacher in this sample all were. Given that middle-class women were relative newcomers to the American work force in this period, and given the sex-segregated nature of employment then, ${ }^{15}$ most Iowa DAR members who worked outside the home chose predominantly female occupations (see table 6). Among these employed DAR members, teaching primary or secondary school was by far the most popular choice, followed by white collar office work (often in male relatives' businesses). DAR women also ran business colleges (in the case of Elizabeth Irish of Iowa City), dressmaking businesses, and millinery shops. Mary H. S. Johnson was the mayor of Humboldt.

The occupations and careers of Iowa DAR members' male relatives also situate them in the upper middle class. A majority (61.9 percent) of their fathers were described as "farmers," a so-

15. See Alan Dawley, Struggles for Justice: Social Responsibility and the Liberal State (Cambridge, MA, 1991), 75, 85; and Alice Kessler-Harris, Out to Work: A History of Wage-Earning Women in the United States (New York, 1982), 75-250. 
TABLE 7

OCCUPATIONS OF DAR MEMBERS' FATHERS AND HUSBANDS

\begin{tabular}{lrrrr}
\hline \multirow{2}{*}{ Occupation } & \multicolumn{2}{c}{ Fathers } & \multicolumn{2}{c}{ Husbands } \\
\cline { 2 - 5 } & $\mathrm{N}$ & $\%$ & $\mathrm{~N}$ & $\%$ \\
\hline Farmers $^{\mathrm{a}}$ & 52 & 61.9 & 25 & 18.2 \\
Businessmen $^{\mathrm{b}}$ & 11 & 13.1 & 40 & 29.2 \\
Public officials $^{\mathrm{c}}$ & 5 & 6.0 & 11 & 8.0 \\
Judges or attorneys $_{\text {Military officers }}$ & 3 & 3.6 & 18 & 13.1 \\
Physicians $^{\mathrm{d}}$ & 3 & 3.6 & 2 & 1.5 \\
Clergymen $_{\text {Other }^{\mathrm{e}}}$ & 2 & 2.4 & 20 & 14.6 \\
$\quad$ & 1 & 1.2 & 5 & 3.7 \\
$\quad$ Total & 7 & 8.3 & 16 & 11.7 \\
\hline
\end{tabular}

SOURCES: See note 4.

"Many of these men were identified as "pioneers" of their communities. This number includes DAR members who were born in rural areas (counties) instead of in towns even if their fathers' occupations were not identified.

'Of 11 DAR members' fathers who were businessmen, 8 either were executives or owned their businesses. Among the husbands, 7 were bankers; 21 others, more than half of this category, owned their businesses, including 3 contractors and a mortician. 'For the fathers, this number includes 4 local officeholders and one state legislator; for the husbands, it includes 4 local officeholders, 4 U.S. congressmen, and 3 state legislators. ${ }^{\mathrm{d}}$ This category includes, among the husbands, one dentist and one osteopath.

'For the fathers, this number includes two college presidents, an engineer, a newspaper publisher, an author, a house builder, and a harness maker. For the husbands, it includes 4 newspaper owners or publishers, 4 railroad agents or engineers, 3 school superintendents, 2 engineers, a journalist, an author, and a letter carrier.

cially elastic term encompassing landowners both large and small. ${ }^{16}$ Most fathers who opted for the towns joined the local elite. They were business owners and executives, local and county officeholders, and high-ranking military officers. Fathers also joined the new professions. A much greater percentage of DAR members' husbands joined the ranks of the professions that increasingly defined the upper middle class. Of those Iowa DAR members whose husbands' occupations are known, less than 20 percent married men who worked the land. Most married successful town or urban capitalists, professionals, and politicians. DAR members' husbands were businessmen and bankers (a combined total of 29 percent); physicians, attorneys, and judges (a combined total of 28 percent); and local, state, and na-

16. No DAR members' obituaries mentioned their mothers' occupations. 
tional politicians. In considering many Iowa DAR members' intense conservatism in the 1920s, the preponderance of property and business owners among their husbands and fathers is very suggestive (see table 7).

This analysis of Iowa DAR members' biographical data reveals that most belonged to America's middle and upper middle classes and to their communities' political and business establishments. On the national level, these Iowa townspeople helped lend a degree of social diversity to the DAR's membership. The DAR's critics viewed the organization as an exclusive preserve of eastern brahmins and other "aristocrats." However, the DAR also attracted Iowa women who did not fit that stereotype, such as Nettie Eels, who owned and ran an Ida Grove millinery shop and who never married; Amelia Gabbert, a Davenport music teacher and church organist who also never married; and Ruth Long Ahlgren, who married a successful Shenandoah car dealer, sat on the board of the local public library, and frequently traveled abroad. ${ }^{17}$ Eels, Gabbert, and Ahlgren moved in very different social worlds from each other and from those of national DAR Presidents General Letitia Green Stevenson, married to U.S. Vice-President Adlai Stevenson, and Grace Hall Lincoln Brosseau, married to the president of Mack Trucks.

WHY DID THESE IOWA WOMEN JOIN the Daughters of the American Revolution? Lacking their own explanations of why they joined, we must examine their actions. In the act of applying for membership, they demonstrated an interest in genealogy. Joining the DAR required documentary proof that an ancestor had either fought on or otherwise aided the American side in the Revolutionary War. Gathering such proof, generated in a time of

17. "Miss Nettie Eels Called Suddenly," n.d. [November 1935], otherwise unidentified clipping; "Miss Amelia Gabbert, Noted Musician Here, Dies at the Age of 81," 24 February 1947, otherwise unidentified clipping; both in State Chaplain's Record/Necrology Rolls Scrapbook, vol. 1, 1903-1948; "Mrs. Ahlgren Dies Sunday in Iowa City Hospital," 9 March 1952; W. D. Archie, "Along the Banks of the Nishna," 11 March 1952; both in Shenandoah Evening Sentinel clippings, State Chaplain's Record/Necrology Rolls Scrapbook, vol. 2, 1948-1957, both scrapbooks in box 2, DAR Collection. 
relatively poor record keeping, demanded time and effort, especially if the ancestor had not been an officer or otherwise socially prominent. Thirty-three DAR members in the sample (11 percent) continued their genealogical studies and, in a few cases, became professionals. DAR members also belonged to other ancestral organizations, such as the Daughters of American Colonists, the Society of Mayflower Descendants, and the National Society of Colonial Dames of America, groups with stricter and narrower requirements for membership than those of the DAR. ${ }^{18}$

Iowa women joined the DAR in especially large numbers after the DAR encouraged them to study the histories of their state and their communities. Because the appeal of studying Revolutionary history year after year was somewhat limited in the trans-Appalachian West, the DAR's national leadership began to pursue a more flexible strategy. Established in 1903, the NSDAR Committee on Historic Spots encouraged DAR members to study their own states' histories and to educate others about them by marking with monuments or plaques "historic spots" in their communities. ${ }^{19}$ Iowa DAR members responded

18. In the sample of 33 DAR members, 15 belonged to the Daughters of American Colonists, 10 to the Society of Mayflower Descendants, 7 to the Colonial Dames (obituary writers did not distinguish between the Colonial Dames of America and the National Society of Colonial Dames of America, separate organizations with similar requirements for membership), 5 to the U.S. Daughters of the War of 1812, 3 to the Huguenot Society, and one each to the Magna Charta Dames, the First Families of Virginia, the Alden Kindred of America (descendanțs of the Alden family on the Mayflower), and the Daughters of the Barons of Runnymede. (The numbers add up to more than the number in the sample because the women tended to belong to more than one of these organizations.) Nine held state or national leadership positions. Four additional members indicated that they were genealogists by hobby or profession.

19. Excerpt from minutes of National Board of Management meeting, 6 May 1903, quoted in "History of the Organization and Work of the Committees," in History of California State Society, Daughters of the American Revolution, 18911938, comp. Mrs. Walter S. Morley (Berkeley, CA, 1938), 108. Particularly in the East, the DAR converted hundreds of old houses into house museums. See Lewis Barrington, Historical Restorations of the Daughters of the American Revolution (New York, 1941); Patricia West, "The Historic House Movement in America: Louisa May Alcott's Orchard House as a Case Study" (Ph.D. diss., State University of New York at Binghamton, 1992), 46-58; and Barbara J. Howe, "Women in Historic Preservation: The Legacy of Ann Pamela Cunningham," Public Historian 12 (1990), 31-61. 
enthusiastically, commemorating the anniversary of Iowa's statehood with a reverence reminiscent of the DAR's attempted solemnification of Fourth of July celebrations. Iowa state DAR historian Alma L. McMahon proposed to the 1911 state conference that the day "be observed by schools and other organizations with rhetorical and military exercises as a day of rejoicing and patriotic thanksgiving. ${ }^{20}$

In particular, the national DAR encouraged the study and celebration of the history of "pioneers" (white Anglo-American settlers). DAR members integrated the stories of nineteenthcentury westward migration into their celebratory narratives of the nation's origins. In conquering the West, pioneers replicated the founders' actions and spread their republican ideas; indeed, they birthed the nation. Reflecting in 1906 on America's new overseas empire as well as on Iowa's "humble" pioneers, state regent Rowena Edison Stevens called the pioneers' search for "an abiding place where they may enjoy freedom of thought and the fruits of their toil ... the great power which conquers the world and leads the march of civilization." ${ }^{21}$ Midwestern and western women in the DAR, then, studied the history of their states with the aim of promoting nationalism.

While continuing to study Revolutionary history, they delved into the history of white settlement. They did not define as "pioneers" only those white settlers who had fought in Indian wars and first staked land claims. Because most DAR members themselves lived in towns, they centered their histories around the white families who had founded towns, cities, and businesses. The DAR chapter in Jefferson, Iowa, for example, marked the sites of Jefferson's first brick house and

20. Alma L. McMahon, report of the State Historian, in Iowa DAR, Twelfth Annual Conference 12 (1911), 16.

21. NSDAR, "Proceedings of the Continental Congress," American Monthly 28 (1906), 584. My analysis of the Iowa DAR's treatment of pioneers is indebted to John Bodnar's discussion of midwestern pioneers and the politics of memory in Remaking America: Public Memory, Commemoration, and Patriotism in the Twentieth Century (Princeton, NJ, 1992), 16-19, 135. He argues that while "ordinary people," representing "vernacular culture," viewed pioneers as personal and local symbols, midwestern elites, promoting an "official culture," viewed them as builders of the nation. 
of the first courthouse, as well as the portions of the old Sioux City and Des Moines trails running through the town. Two chapter members also wrote and gave papers covering the histories of Floyd and Black Hawk Counties. Both papers began with the first white trapper or permanent settler rather than with Native American history or the first European explorers. Both members also recounted the birth of the first white child, the first village, the first store, the first school and teachers, the first frame house, and the first newspaper in their respective counties. ${ }^{22}$

Because of the DAR's near sacralization of George Washington, many dismiss DAR history as history dominated by great men. Although DAR members in Iowa and elsewhere devoted considerable time and energy to praising the "Founding Fathers," they also educated themselves and others in the history of women and the history of "pioneer women" in particular. Their models celebrated historic women for both their domesticity and their willingness to go to war for the nation. In 1927 the DAR erected twelve identical statues of the "Pioneer Mother of the Trail" along old trails across America, from Maryland to California. The "Pioneer Mother" held a rifle in one arm and a baby in the other. ${ }^{23}$ Iowa DAR members were eager students of women's history: in 1922, when NSDAR Historian General Alice McDuffee asked DAR members to collect "sketches" of the lives of five historically significant women in their states, Iowa sent fifty. ${ }^{24}$ The Iowa DAR's study of state and local history sustained its members' interest, and so ensured its future growth.

22. Typescript lists of "Iowa Historic Spots," n.d. [1920s and after], folder 3, box 1; Margaret Allen Cain, Historian's Report, 1921-1922, Independence Chapter DAR (Jefferson, Iowa) Historian's Scrapbook, 1910-1937, box 6; "Beginnings in Floyd County," typewritten paper, n.d. [after 1921], and Mrs. George De Wald, "Sketch of the Early History of Black Hawk County," typewritten paper, 1921, both in folder 2, box 1, all in DAR Collection.

23. Daughters of the American Revolution Magazine 61 (1927), 480; Fern Ioula Bauer, The Historic Treasure Chest of the Madonna of the Trail Monuments, rev. ed. (1986; reprint, Springfield, OH, 1993). I would like to thank Pamela H. Simpson for directing me to the latter source.

24. NSDAR, Proceedings of the Continental Congress 31 (1922), 60-61. 


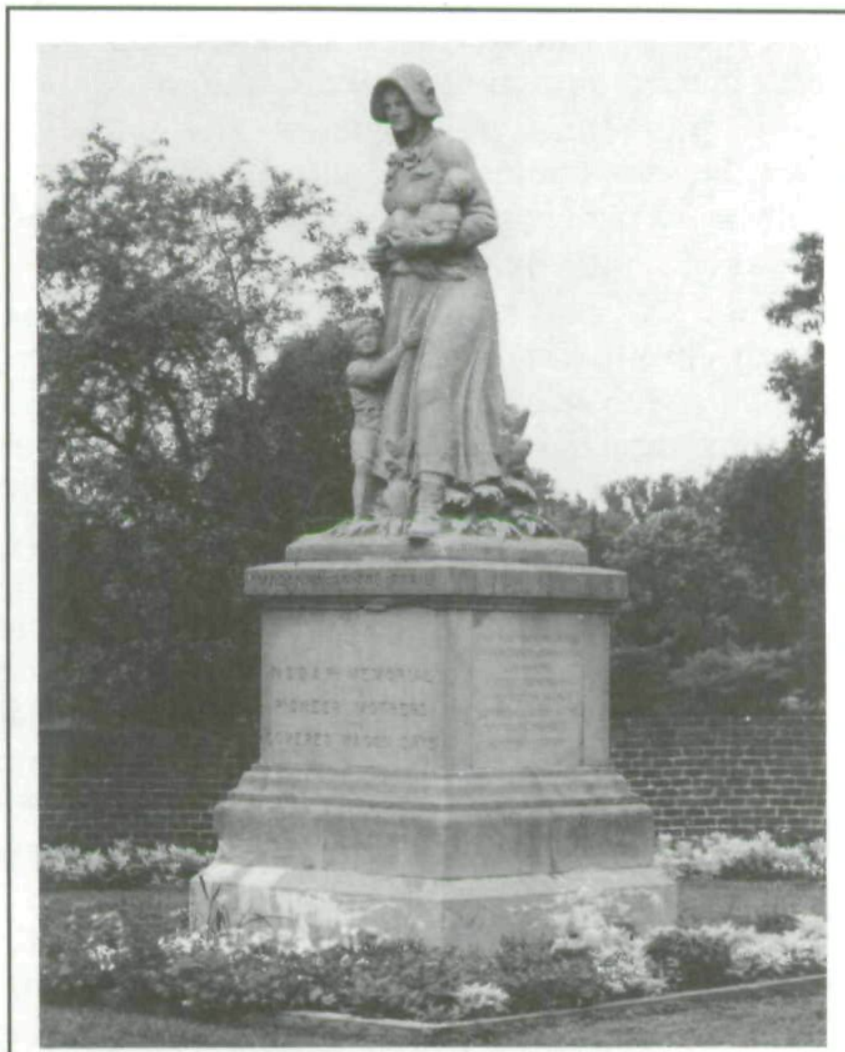

This Pioneer Mother of the Trail statue is located on the Old National Road near Springfield, Ohio. Photo courtesy Charles A. Thomas Photography, Springfield, Ohio.

ANOTHER FACTOR in the DAR's growth in Iowa was the DAR's engagement in a wide range of nonhistorical activities under the broad rubric of promoting patriotism. These various projects, like the promotion of the history of white settlement of the West, did not require the presence of Revolutionary landmarks.

During the Spanish-American War and World War I, the Iowa DAR engaged in extensive war relief efforts. In 1898 it raised money and shipped goods to invalid and wounded soldiers in camps in the South. Starting in 1916, the Iowa DAR raised hundreds of thousands of dollars for the war effort, 
made goods such as bandages for American soldiers, promoted the domestic conservation of food, wool, and other goods, and cooperated with the Red Cross. Members also educated themselves about the war effort: in 1917 and 1918, the DAR chapter in Waucoma heard papers on topics such as "America's Contribution to War Machines" and "The Feeding of an Army." The secretary of the Jefferson DAR chapter reported in 1918 that "We have cut out all social affairs and given our money and our time to Patriotic and War Relie[f] Work." ${ }^{25}$

At all levels during World War I, the DAR aggressively promoted heightened patriotism and "loyalty" in themselves and others, often cooperating with local and county branches of the Women's Committee of the Council of National Defense, the federal umbrella agency directing civilian war relief activities. The regent of the Jefferson DAR chapter, Neva Allen Cockerill, also chaired the Jefferson unit of the Women's Committee, and among the chapter's members was the Women's Committee's county chair. ${ }^{26}$ Iowa DAR members also tried to instill "loyalty" in others on an individual basis. Mabel Pratt Schoentgen's patriotic counseling of a German-American woman in Council Bluffs was fraught with patriotic emotion and ritual. At the 1919 state conference, as Schoentgen reported on Iowa chapters' contributions to the DAR's Liberty Loan fund, she paused to describe her encounter with an unnamed woman who had lived in the United States "some thirty years." The woman had been aggrieved by the tone of what Schoentgen described as a "rousing, patriotic talk" given by a military man at the local YWCA. During the talk she whispered to Schoentgen, "'You don't know how bad that makes me feel. My countrypeople were kind and good when I lived there and it hurts me to hear such awful things about them.'" Schoentgen told her sternly, "'You have come to the parting of the way; you must be a good, loyal

25. Chapter Program, Waucoma Chapter DAR (Waucoma, Iowa), 1917-1918, programs and history folder, DAR Collection; Eva Child Head, "Independence Chapter D.A.R.," typescript, Independence Chapter DAR (Jefferson, Iowa) Historian's Scrapbook, 1910-1937, box 6, DAR Collection.

26. Eva Child Head, "Independence Chapter D.A.R.," typescript; Neva Allen Cockerill, Chapter Report, 1 February 1918, typescript; Independence Chapter DAR (Jefferson, Iowa) Historian's Scrapbook, 1910-1937, box 6, DAR Collection. 
American or you will be classed among the pro-German.' 'I want to do what is right, I want to be loyal, I want to do my duty,' she answered." Schoentgen produced two little American flags. "And so the little ceremony took place. I pinned a small American flag on her coat over her heart, and she pinned one on me, and as she did so I felt as if I were repledging my love and devotion to my country."${ }^{\prime 27}$

THE DAR'S PATRIOTIC ACTIVITIES in peacetime were even more varied, and they changed drastically over time. Before World War I, DAR members' projects and rhetoric situated them in the mainstream of the benevolent, politically moderate progressivism favored by upper and middle-class women working through voluntary associations to effect reform. DAR members constructed definitions of patriotism that harmonized with their social activism. One leader, for example, defined patriotism as "the developing of our sense of justice." ${ }^{28}$ In keeping with such definitions, DAR members in Iowa and elsewhere promoted state and federal governments' involvement in social problems. In Cedar Falls, for example, the topic of discussion at a 1912 DAR chapter meeting was "What the government might do in the area of social and human welfare work." ${ }^{29}$

Like other Progressive Era clubwomen, Iowa DAR members took a particularly strong interest in women and child industrial workers. ${ }^{30}$ In 1907 the Iowa DAR formed a Child Labor Committee. For the next four years, Iowa DAR members, in

27. Iowa DAR, Twentieth Annual Conference 20 (1919), 64. In 1920 Schoentgen was elected one of seven NSDAR Vice-Presidents General.

28. Clara Hadley Wait, "Patriotic Education," Speech to the Algonquin Chapter DAR (St. Joseph and Benton Harbor, MI), quoted in "State Regent D.A.R. Meets Local Chapter," 12 December 1913, otherwise unidentified clipping in Scrapbook, vol. 2 (1895-1914), 20, box 1, Clara Hadley Wait Papers, Michigan Historical Collections, Bentley Library, University of Michigan, Ann Arbor.

29. Minutes, 16 November 1912, Black Hawk Chapter DAR (Cedar Falls, Iowa) Record Book, 1905-1919, 101, DAR Collection.

30. At a November 1907 meeting of the Independence DAR chapter, members discussed readings on child labor. They then signed petitions to state legislators. Minutes, 7 November 1907, Penelope Van Princes Chapter DAR (Independence, Iowa) Secretary's Book, 1903-1910, box 8, DAR Collection. 
cooperation with the independent National Committee on Child Labor and the NSDAR Committee on Child Labor, lobbied unsuccessfully for a stronger state law on child labor. ${ }^{31}$ They opposed child labor not only on moral and humanitarian grounds, but also because it converted future workers into burdens on the public purse. When Julia Clark Hallam, chair of the Iowa DAR's Child Labor Committee, enjoined the 1909 state conference to boycott clothes, particularly underwear, made in sweatshops, she claimed that "manufacturers are allowed to cripple and deform children and the public is required to support them afterwards." She called child labor "one of the most fruitful sources of demand for charity." ${ }^{\prime 32}$

After the federal Children's Bureau was established in 1912 (something Iowa DAR members had called for since $1908^{33}$ ), Iowa DAR members cooperated with its chief, Julia C. Lathrop, in promoting reforms in other areas of child welfare. Alice Day Marston of Ames, then chair of the Iowa DAR's Committee on the Welfare of Women and Children (which replaced the Committee on Child Labor in 1911), wrote to Lathrop in November 1914 asking her for suggestions on work for the DAR and expressing frustration at the DAR's abandonment of lobbying. Lathrop suggested that Marston's committee petition the state legislature for "the great need in Iowa, - a good vital statistics law," because of DAR members' interest in genealogy: "The records of historical societies are certainly full of incidents showing the need of birth registration as a means of identification in tracing family history." ${ }^{134}$ The Children's Bureau's efforts

31. See the reports of the Iowa DAR Child Labor Committee to the Iowa state conference. Iowa DAR, Eighth Annual Conference 8 (1907), 2; idem, Ninth Annual Conference 9 (1908), 35-36; idem, Tenth Annual Conference 10 (1909), 23; idem, Eleventh Annual Conference 11 (1910), 29-31; idem, Twelfth Annual Conference 12 (1911), 4.

32. Hallam told the conferees that she had "reason to believe" that some Iowa stores handled merchandise from such sweatshops, and she instructed them on where in Iowa they could find the National Consumer League's white label. Iowa DAR, Tenth Annual Conference 10 (1909), 26-29.

33. Iowa DAR, Ninth Annual Conference 9 (1908), 35-36.

34. Marston to Lathrop, 27 November 1914, and Lathrop to Marston, 1 December 1914, Central File 4-0-1 (1914-1920), box 23, Records of the Children's Bureau, U.S. Department of Labor, RG 102, National Archives and Records Ad- 
to promote birth registration laws complemented its campaigns to decrease rates of infant mortality. (They also reflected a typically progressive impulse to facilitate the collecting of statistics; Lathrop called it "the basis for an intelligent understanding of work for children." ${ }^{\prime 35}$ ) Defeated in 1915, Marston and the Iowa DAR had limited success two years later when the state legislature passed a birth registration law that made the county, not the locality, the unit of registration. When the Iowa DAR disbanded its Committee on Welfare of Women and Children because of the war, Iowa DAR members' work in the area of child welfare ended (although the DAR as a national body in 1921 supported the Sheppard-Towner Act, the first federal system of pensions for poor women with children). ${ }^{36}$

Between the mid-1890s and the mid-1920s, the Iowa DAR, and the DAR nationwide, worked extensively on another project that situated them in the progressive mainstream: the "patriotic education" of new immigrants, millions of whom arrived in America during this period. During World War I, this work, which consisted primarily of instruction in the English language and American history, became known as "Americanization." ${ }^{37}$ The DAR pursued Americanization work in order to hasten the immigrants' linguistic, political, and cultural assimilation. Immigrant men attended night schools while immigrant women were instructed in their homes. In 1921 the DAR began distributing its Manual for Immigrants in six dif-

ministration, College Park, MD; Alice Day Marston, Report of the Committee on Welfare of Women and Children, Iowa DAR, Sixteenth Annual Conference 16 (1915), 103-7. See also Robyn Muncy, Creating a Female Dominion in American Reform, 1890-1935 (New York, 1991), 59.

35. Lathrop to Marston, 27 February 1915, Central File 4-0-1 (1914-1920), box 23, Records of the Children's Bureau.

36. Alice Day Marston, Report of the Committee on Welfare of Women and Children, Iowa DAR, Eighteenth Annual Conference 18 (1917), 133. On the DAR's support for the Sheppard-Towner Act, see Daughters of the American Revolution Magazine 54 (1920), 356; NSDAR, Proceedings of the Continental Congress 29 (1920), 82, 278.

37. See John Higham, Strangers in the Land: Patterns of American Nativism, 1860-1925, rev. ed. (New York, 1963), 234-63; and John F. McClymer, "Gender and the 'American Way of Life': Women in the Americanization Movement," Journal of American Ethnic History 10 (1991), 4-18. 
ferent languages. ${ }^{38}$ The manual provided immigrants with information on everything from George Washington to flag desecration to dealing with landlords and also served as a study guide for citizenship tests.

DAR members' confidence in their own social and (as they defined the word) racial superiority informed their work among immigrants. Viewing themselves as authorities on Americanism, they believed that immigrants desiring citizenship should not merely learn English, but also should emulate the DAR members' own Anglo-American customs and culture. However, DAR members also based their Americanization work on the assumption that American citizens were made as well as born, and that any immigrant could choose to become one. These assumptions lay behind the actions of Mabel Pratt Schoentgen, when she wrung a declaration of loyalty out of a German-born woman at the height of World War I. The DAR's nationwide custom of holding receptions for newly naturalized U.S. citizens also exemplified this inclusive spirit.

When working with immigrants, many DAR members policed their own attitudes towards them. At a July 1919 meeting of the chapter in Mt. Vernon, a member read aloud a communication from the Iowa DAR Committee on Americanization enjoining rank-and-file members "to welcome newly arrived foreigners to a place in our national and civic life"; to visit female immigrants in their homes in order "to help them to rise to better conditions of life"; and "to forbid use of all terms of derision applied to foreigners." At a November 1920 meeting, chapter members discussed Americanization extensively. "We didn't succeed in solving the problem of Americanization of the foreigners," wrote the chapter secretary, "which has baffled the wisest most capable men of our day but I think we have learned in the study of Americanization something of how not to treat the foreigner." The women taking part in

38. In 1923 the national DAR distributed the Manual for Citizens in English, Italian, Polish, Yiddish, Hungarian, and Spanish. NSDAR, Proceedings of the Continental Congress 32 (1923), 48. By 1928, they had added Russian, Chinese, and Japanese. 
these discussions in Mt. Vernon clearly wanted immigrants to feel welcome in their new country. ${ }^{39}$

Iowa did not attract as many immigrants as other, more industrial midwestern states, but it attracted enough of them for the Iowa DAR to form its Committee on Americanization. ${ }^{40}$ As early as 1904, the Iowa state historian reported to the state conference that the Iowa DAR was sponsoring lectures on "patriotic subjects" for the "large foreign element" in Iowa's larger cities and towns, illustrated by slides (they used a stereopticon), "for often a picture will arouse a spark of patriotism when the words of the lecturer may pass unheeded."41 In Des Moines, DAR members worked with immigrant children and particularly with boys. In 1907 the Des Moines DAR chapter cooperated with the Des Moines Federation of Women's Clubs in running "Newsboys' Clubs." The chapter went on in 1909 to organize a "Children of the Republic" club strictly under DAR auspices at Des Moines's Roadside Settlement. ${ }^{42}$ Iowa DAR members also ran night schools for immigrant men. In 1922 a paper Stella McCord delivered to the Newton DAR chapter on local "Interesting Women" included two sisters, Mrs. J. A. McCalmont and Bertha Fehleisen, who started in 1921 what McCord erroneously claimed was the "first school in Americanization in the United States for Mexicans." Starting with eighteen Mexicans, one Argen-

39. Minutes, 2 July 1919, 3 November 1920, Balliet Chapter DAR (Mt. Vernon, Iowa) Historian's Book, 1914-1962, 33-34, 41-42, box 11, DAR Collection.

40. The 1895 state census identified only 326 of the 72,888 people living in Polk County (containing Des Moines) as "non-naturalized foreigners." Ten years later, partly because the census changed its method of counting immigrants, the numbers had risen precipitously. In 1905, 42 percent of Iowa's population, and 32.5 percent of the population of Polk County, was either foreign-born or native-born of foreign-born parents. Census of Iowa for 1895, 163-240; Census of Iowa for 1905, 474-81, 486-89. By contrast, in 1890, 78 percent of Chicago's population was either foreign-born or native-born of foreign parents. Muncy, Creating a Female Dominion, 11.

41. Sophia Hyndshaw Bushnell, "State Historian's Annual Report," Iowa DAR, Fifth Annual Conference 5 (1904), 20-21.

42. Mary Rebecca McKnight, Report of the Chairman of the Iowa Patriotic Education Committee, Iowa DAR, Eighth Annual Conference 8 (1907), 21; Minutes, 8 November 1909, Abigail Adams Chapter DAR (Des Moines) Secretary's Book, 1909-1921, box 7, DAR Collection. 
tine, and one Austrian, all of whom worked in nearby coal mines, the sisters ran a three-month night school offering "American business methods and manner of living." ${ }^{\prime 43}$

In the late 1920s, as the DAR veered to the right, it redefined its "Americanization" work as "Americanism" work. The DAR Committee on Americanization changed its name because DAR leaders and members came to believe that radicalism lurked not only among the foreign-born, but also among progressive reformers and peace activists with Anglo-American surnames like Addams and White. In 1927 the Iowa DAR's Committee on Americanization recommended that Americanization work be redirected toward "making a good American citizen of everyone who dwells on American soil." ${ }^{44}$

IN THE MID-1920s, as DAR members began to elect national leaders who belonged to or sympathized with the antiradical and antireformist far right, the DAR's nonhistorical public activities changed in their definition and focus. At the same time, the DAR continued to grow in Iowa, albeit more slowly (see table 1). After the Bolshevik Revolution in Russia in 1917 and the Red Scare of 1919, DAR leaders and many members began to view Bolshevist hopes for international revolution as an immediate threat to the United States and continued American military strength as an immediate necessity. The DAR increasingly shared members, leaders, and projects with militaristic organizations such as the American Legion Auxiliary rather than with the reformist General Federation of Women's Clubs. ${ }^{45}$

43. Stella McCord, "Interesting Women," 1922 notes, Isham Randolph Chapter DAR (Newton, Iowa) Historian's Book, 1917-1937, 51, box 12, DAR Collection. DAR members worked extensively with Mexican immigrants in California, Texas, and the Southwest starting in the 1910s.

44. Iowa DAR, Twenty-Eighth Annual Conference 28 (1927), 42; Iowa DAR, Twenty-Ninth Annual Conference 29 (1928), 44.

45. Eighteen Iowa DAR members out of 237 ( 7.6 percent) listed the American Legion Auxiliary among their club affiliations; many of them were local leaders. On the national level, between 1922 and 1930, six out of seven of the American Legion Auxiliary's national presidents were DAR members. Edith Irwin Hobart, the Auxiliary's first president starting in 1920, went on to lead the DAR from 1929 to 1932. NSDAR, Proceedings of the Continental Congress 39 (1930), 19. On 
These trends intensified in 1926 with the establishment of the DAR's powerful National Defense Committee, chaired by VicePresident General Flora Bredes Walker of Seattle. Emphatically rejecting the DAR's previous connections to reform, the National Defense Committee viewed progressive individuals and groups in general, and peace groups such as the Women's International League for Peace and Freedom (WILPF) in particular, as shelters for radical "borers from within." At the National Defense Committee's direction, DAR members everywhere pressured institutions in their communities, sometimes successfully, not to host lecturers from such organizations. The DAR's former heroes and partners in reform such as Jane Addams (herself a DAR member as late as 1923) became its enemies. ${ }^{46}$

At all levels of the DAR, the National Defense Committee disseminated pamphlets and other materials generated by military officers, manufacturers' associations, and other groups constituting the far right in the 1920s. The right declared war on progressive women's clubs and peace groups, both of which lobbied Congress to reduce War Department appropriations. The far right also circulated "spider-web charts" purporting to link reformist women's clubs with Moscow through a plethora of connecting lines (see page 86 below). It also generated more straightforward lists of suspected "reds" and their sympathizers, labeled "pinks" or "yellows." ${ }^{17}$ Because of its progressive heri-

the DAR's alliance with the American Legion against the Women's International League for Peace and Freedom in Sioux City, see Kim E. Nielsen, "Dangerous Iowa Women: Pacifism, Patriotism, and the Woman-Citizen in Sioux City, 1920-1927," in this issue.

46. On Addams's joining the DAR in 1900, see Allen F. Davis, American Heroine: The Life and Legend of Jane Addams (New York, 1973), 267. In December 1923 the Chicago DAR Chapter elected Jane Addams a life honorary member. Ellen Starr Brinton, "An Unwritten History of the D.A.R.," typescript, n.d. [1940], 16, "Unpublished Works, Daughters of the American Revolution," box 2, Ellen Starr Brinton Papers, Swarthmore College Peace Collection, Swarthmore, PA.

47. Nancy F. Cott, The Grounding of Modern Feminism (New Haven, CT, 1987), 248-51; Davis, American Heroine (New York, 1973), 251-74; Joan Jensen, "All Pink Sisters: The War Department and the Feminist Movement in the 1920s," in Decades of Discontent: The Women's Movement, 1920-1940, ed. Lois Scharf and Joan Jensen (Boston, 1987), 199-222; J. Stanley Lemons, The Woman Citizen: Social Feminism in the 1920s (1973; reprint, Charlottesville, VA, 1990), 209-227; 
tage and its support of the Sheppard-Towner Act in 1921, the DAR itself appeared on at least one such chart in the early $1920 \mathrm{~s}^{48}$ It was removed when it proved eager to circulate and disseminate such materials generated by the far right as the "Daily Data Sheets" compiled by Fred R. Marvin of the Key Men of America (to which the DAR National Defense Committee encouraged DAR members to subscribe ${ }^{49}$ ), articles in the antifeminist Woman Patriot (formerly an antisuffrage journal), and published speeches by high-ranking military officers.

Some Iowa DAR members had become dedicated opponents of "subversion" even before the DAR Continental Congress voted the National Defense Committee into existence in 1926. In 1925, in an effort to expose what she considered overly zealous actions by DAR leaders, Lucile Amlie of Spencer mailed copies of a spider-web chart known as the "yellow list" (the least radical gradation of subversive) to local newspapers. Amlie alleged that Mrs. E. R. Holland of Des Moines, chair of the Iowa DAR Committee on Patriotic Education, had sent the chart, which included such nonradical organizations as the YMCA, to the Spencer DAR chapter. ${ }^{50}$ In 1928 the Iowa DAR state conference affirmed its support of the National Defense Committee's mis-

Kim E. Nielsen, "The Security of the Nation: Antiradicalism, Gender, and the Red Scare of 1918-1928" (Ph.D. diss., University of Iowa, 1996).

48. Lucia Ramsey Maxwell of Washington, a librarian in the War Department, compiled the best-known spider-web charts. On her first one in the spring of 1923, she listed the DAR. Ironically, Maxwell herself also belonged to the DAR.

"The Socialist-Pacifist Movement in America Is an Absolutely Fundamental and Integral Part of International Socialism," chart compiled by Lucia Ramsey Maxwell, May 1923, MID file 10110-1935, item 24, Military Intelligence Division Correspondence (1917-1941), box 2826, RG 165, National Archives and Records Administration, Washington, DC; Gibbs, The DAR, 109.

49. The minutes of the 2 November 1927 meeting of the Balliet Chapter DAR in Mt. Vernon, Iowa (Secretary's Book, 1924-1931, 63, box 11, DAR Collection), reveal that the group considered following the suggestion of the National Defense Committee to subscribe for membership in the Key Men of America, "an organization dedicated to the exposure of enemies of American ideals, wherever found."

50. "'Yellow List' Provokes Ire and Laughter," Des Moines Tribune-Capital, 17 April 1925, clipping, folder "Attackers: Daughters of the American Revolution -Clippings about the D.A.R. (1924-1929)," box "Daughters of the American Revolution," Special Collections: Attackers, Swarthmore College Peace Collection. 
sion, resolving that the Iowa DAR "undertake a specific program of action" including "intense individual research, group study-classes, lectures and public meetings in the determination ... to bring about a clean cut cleavage between un-American subversive forces and the constituents of Patriotic societies." The conference also enjoined Iowa DAR members to ask their congressmen to "support . . . adequate appropriations for all branches of National Defense. ${ }^{\prime 51}$

The National Defense Committee's programs found a ready audience among Iowa DAR women. By the second year of the committee's existence in Iowa, more than half of the state's chapters were taking up its work. In 1929 the Iowa state chair of national defense reported that fifty-six Iowa chapters (out of 105 in 1928) were studying national defense and were writing to their congressmen in support of a naval appropriations bill. ${ }^{52}$ In 1931, a depression year, the Iowa DAR's Board of Management pledged 15 percent of the state DAR budget to national defense work. ${ }^{53}$ Some Iowa DAR members also obeyed the National Defense Committee's injunctions to ban from their meetings speakers with whom they disagreed. William Allen White reported in his Emporia, Kansas, newspaper in May 1928 that a few months before, Des Moines's DAR chapter had invited Mrs. Frederick Weitz of Des Moines, the publicity chair of the General Federation of Women's Clubs, to speak. But after the chapter learned that Weitz had recently attended a meeting of the National Conference on the Causes and Cure of War, a moderate peace organization headed by former suffrage leader

51. Minutes, Iowa DAR, Twenty-Ninth Annual Conference 29 (1928), 16-18.

52. Mary B. Frisbee, Report of Committee on National Defense, Iowa DAR, Thirtieth Annual Conference 30 (1929), 77-78.

53. Even after the Great Depression pinched its budget, Iowa DAR leaders continued to appropriate generous amounts of money to the cause of national defense. In 1933 the DAR state budget was reduced by 25 percent, yet 15 percent still went to the National Defense Committee, compared to 10 percent for "Approved Schools and Americanism" (denoting DAR-run and DARsupported schools for immigrants, Native Americans, and Appalachian whites). In 1937 the allocation was reduced to 10 percent. Minutes, 2 March 1931, 6 March 1933, and 8 March 1937, Iowa Society DAR Board of Management, 1930-1950 Book of Minutes, n.p., box 1, DAR Collection. 
Carrie Chapman Catt, it abruptly disinvited her on the day she was scheduled to speak. ${ }^{54}$

Because the DAR National Defense Committee's expansive definition of "subversives" encompassed many liberals and progressives who were in fact antiradical themselves, it alienated a handful of DAR members who openly protested, and perhaps many more DAR members who kept their silence. These members had not discarded their affiliations with the peace movement or with progressive reform. Some of them were married to prominent professors and clergymen whose names appeared on lists of "doubtful speakers" circulated by the DAR. Galvanizing their protests was the February 1928 appearance of Flora Bredes Walker, chair of the DAR's National Defense Committee, before the U.S. House Committee on Naval Affairs. She agreed with right-wing congressmen who called for investigations of "suspicious" people and activity in women's peace groups. ${ }^{55}$ Her claim that she was speaking for the entire DAR antagonized progressive DAR members, some of whom formed a short-lived but highly visible "DAR Committee of Protest." Concentrated mostly in college towns such as Palo Alto and New Haven, it was led by Helen Tufts Bailie of Cambridge, Massachusetts. After she publicized a list of "doubtful speakers" circulated by the Massachusetts National Defense Committee in February 1928, the DAR's national leadership expelled her. Her purge attracted support for the Committee of Protest. Between 1928 and 1930, the committee inspired tens and perhaps hundreds of other women to resign from the DAR.

Some Iowa women were among those DAR members who openly disagreed with the DAR's new antiradicalism and attacks on reformers. Lucile Amlie's effort to bring a DAR-distributed "yellow list" to the attention of Iowa newspapers predated the

54. "Lady Sheep," Emporia Weekly Gazette, 3 May 1928, folder 7 ("Clippings"), box 1, DAR "Blacklist" Controversy Collection, Stanford University Special Collections, Stanford, CA.

55. U.S. House Committee on Naval Affairs, "Statement of Mrs. Sherman D. Walker [sic], Vice-President and Chairman of Committee on National Defense and E. B. Johns on . . . a Bill for the Increase of the Naval Establishment," 17 February 1928, Committee Serial No. 47, 70th Cong., 1st sess. (Washington, DC, 1928), 1391-1466. 
founding of the National Defense Committee. The name May B. Ditch of the Ottumwa Public Library appears on the Committee of Protest's own lists of "sympathetic" DAR members. ${ }^{56}$ Even unsuccessful actions indicate pockets of resistance to the $\mathrm{Na}$ tional Defense Committee's militarism. At the 1928 state conference, delegates voted down a resolution urging the United States to enter "such compacts and agreements with the other nations of the world as are designed to do away with war, as a means to settle international disputes. ${ }^{157}$ At a meeting of the Mt. Vernon DAR chapter in November 1931, the secretary recorded without comment that "before adjournment a letter for Disarmament was placed on the table where anyone who wished to do so might sign it." This letter was never mentioned again, and the chapter engaged in national defense activities on other occasions. ${ }^{58}$ Many more Iowa DAR members and chapters soon adopted the programs and resolutions of the National Defense Committee. At the 1929 state conference, a majority of delegates supported a resolution implicitly repudiating the DAR Committee of Protest and explicitly affirming the state organization's "allegiance to the National Society, of which we are a part."

The DAR leadership's actions and words in the late 1920s inspired a progressive backlash against it. The "blacklist controversy" made nationwide headlines in $1928 .{ }^{60}$ After Bailie's expulsion, many commentators viewed the DAR as an enemy of free speech. "Muck-raking" investigative journalists documented the DAR's links with the far right, increasingly dogged by its own scandals. Kansas commentator William Allen White made connections between the DAR and the Ku Klux Klan. ${ }^{61}$

56. "Sympathetic D.A.R. Correspondents," February-May 1928; "Correspondents: Sympathetic D.A.R.s," 7 June 1928, both in folder "D.A.R. Revolt," box 8, Special Collections: Attackers, Swarthmore College Peace Collection.

57. Minutes, Iowa DAR, Twenty-Ninth Annual Conference 29 (1928), 16-18.

58. Minutes, 4 November 1931, Balliet Chapter DAR (Mt. Vernon, Iowa) Secretary's Book, 1931-1939, 19, box 11, DAR Collection.

59. Minutes, Iowa DAR, Thirtieth Annual Conference 30 (1929), 20.

60. New York World, 12-16 February 1928.

61. White, who had himself appeared on DAR lists of suspected radicals, charged that the DAR had "yanked the Klan out of its cow pastures and set it down in the breakfast room of respectability." "D.A.R. List a Klan 
Closer to home, Iowa painter Grant Wood, best known for his American Gothic, once commented, "I don't like to have anyone try to set up an aristocracy of birth in a republic." ${ }^{\prime 62}$ After an argument with the DAR chapter in Cedar Rapids over his proposed use of German-made stained glass in a war memorial, Wood painted his satirical Daughters of Revolution in 1932. He juxtaposed the fussy clothes of three thin-lipped, middleaged women and the dainty tea cup one is holding with the exuberantly heroic image on the wall behind them, Emanuel Leutze's Washington Crossing the Delaware. ${ }^{63}$ The image captured for many the comic irony of the DAR's combination of rightwing politics and Revolutionary references. ${ }^{64}$ When Wood first displayed the painting in Cedar Rapids, DAR members there

Mask, Says White," New York World, 6 April 1928, clipping, folder "Attackers: Daughters of the American Revolution - Black List," box "Daughters of the American Revolution," Special Collections: Attackers, Swarthmore College Peace Collection. For other reportage by contemporary "muckraker" journalists, see Vance Armentrout, The Red Brand: A Series of Articles Originally Appearing in the Courier-Journal (Louisville, KY, 1929); Norman Hapgood, ed., Professional Patriots (New York, 1927); Elizabeth McCausland, "The Blue Menace": Reprint from the Springfield Republican (March 19-27, 1928) (Springfield, MA, 1928).

62. Quoted in Des Moines Register, 17 March 1940, clipping, Nathaniel Fellows Chapter DAR (Iowa City) Scrapbook, 1938-1945, DAR Collection. On Grant Wood in general, see Wanda M. Corn, Grant Wood: The Regionalist Vision (New Haven, CT, 1983); and James M. Dennis, Grant Wood: A Study in American Art and Culture (Columbia, MO, 1986).

63. Karal Ann Marling believes that Wood painted the white-haired woman on the left, with her "letter-box mouth," to resemble Gilbert Stuart's George Washington. Karal Ann Marling, George Washington Slept Here: Colonial Revivals and American Culture, 1876-1986 (Cambridge, MA, 1988), 335-37, 345-46. Many contemporaries spotted their own female relatives in the painting, including one man who inquired of Wood, "Where in Heaven's name did you see my Aunt Emma?" Quoted in Nan Wood Graham, with John Zug and Julie Jensen McDonald, My Brother, Grant Wood (Iowa City, 1993), 95.

64. When Daughters of Revolution was displayed at the Century of Progress Exposition in Chicago in 1933, tourists in droves bought postcard reproductions of it. Dennis, Grant Wood, 110-12. At the height of the Marian Anderson controversy in 1939 (see below), NAACP secretary Walter White tried to persuade Time magazine to publish Daughters of Revolution on its cover. Scott A. Sandage, "A Marble House Divided: The Lincoln Memorial, the Civil Rights Movement, and the Politics of Memory, 1939-1963," Journal of American History 80 (1993), 144. 


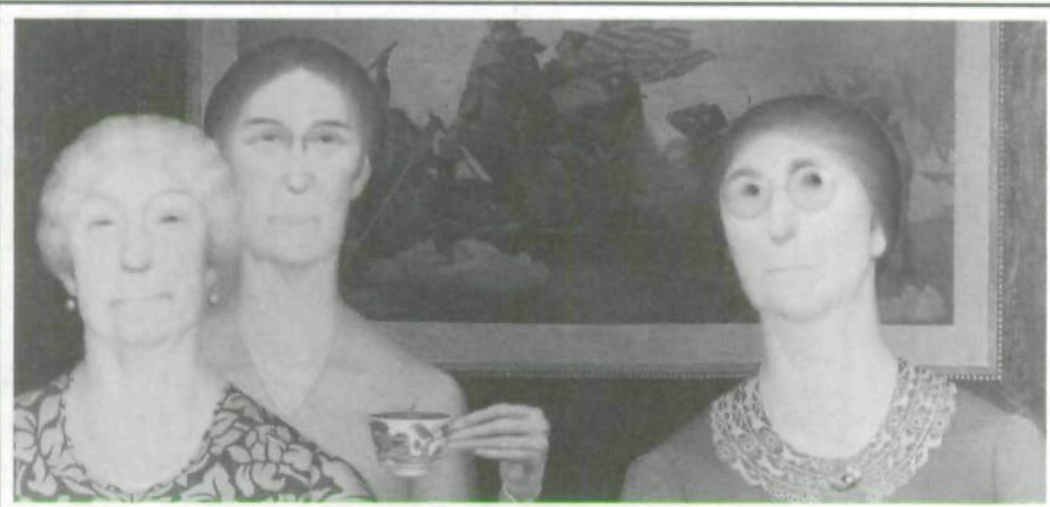

Grant Wood's Daughters of Revolution, courtesy Cincinnati Art Museum, Gift of The Edwin and Virginia Irwin Memorial.

and elsewhere demanded its removal. ${ }^{65}$ Other Iowa DAR members found Daughters of Revolution humorous. Grant Wood's sister recounted that delegates at an Iowa state DAR conference laughed and applauded when the painting appeared in a slide show and that one chapter even invited Wood to lecture. ${ }^{66}$

Iowa's postwar political climate helps explain why DAR membership retained its prestige after America's progressive intelligentsia began to represent the DAR as an embodiment of buffoonish Babbittry. When Iowa DAR members, mostly economically successful women who lived in the state's proverbially procapitalist towns, ${ }^{67}$ embraced the DAR's new right-wing politics, their action occurred against the backdrop of their own state's increasing antiradicalism. Known for its pioneering Des

65. "Painting Brings Protests of Women," Chicago Times, 4 June 1933, clipping, folder "Attackers: Daughters of the American Revolution-Clippings about the DAR (1924-1929)," box "Daughters of the American Revolution," Special Collections: Attackers, Swarthmore College Peace Collection.

66. Graham, My Brother, Grant Wood, 95.

67. Joseph Frazier Wall has questioned the stereotype of conservative Iowa farmers (who joined the Grange in the nineteenth century and the Farmers' Union in the 1920s and 1930s), arguing that the state's true repositories of conservativism were its small towns, where "doctrines of laissez-faire and the free-enterprise system are most fervently and sincerely believed in." Joseph Frazier Wall, Iowa: A Bicentennial History (New York, 1978), 149. 
Moines Plan of city government, Iowa had been a progressive (though not Populist) state before World War I. During his administration, Republican governor Albert Cummins (1902-1908) pushed legislation to regulate railroads, the insurance business, food, and drugs.$^{68}$ During World War I, however, Iowa became known for its zealous promotion of "loyalty." After Governor William L. Harding decreed by executive order that only English could be spoken in all public settings, including church services, five "respectable" German-American farm women were arrested for speaking German on their party line. In 1918 the Iowa state legislature passed one of the country's most loosely worded criminal syndicalist laws. It provided for a twenty-year jail sentence for any person "who by word of mouth or writing advocates . . . violence in accomplishing industrial or political reform." ${ }^{119}$ Against this backdrop, Iowa townswomen continued to join the DAR.

THROUGHOUT THESE POLITICAL CHANGES in Iowa and within the DAR, DAR membership remained a desirable badge of status in Iowa. Besides its preservation of state and local history and its raft of nonhistorical, patriotic projects in the areas of child welfare, the Americanization of immigrants, and antiradicalism, the DAR also appealed to upper middleclass Iowans for reasons of social prestige. Local newspapers covered DAR events in detail. ${ }^{70}$ This remained true in Iowa

68. Dorothy Schwieder, "Iowa: The Middle Land," in Heartland: Comparative Histories of the Midwestern States, ed. James H. Madison (Bloomington and Indianapolis, 1988), 286; Wall, Iowa, 156, 171-73.

69. With the exception of William Sentner during the 1938 Maytag strike, few labor leaders were ever charged under this law. Wall, Iowa, 148, 173.

70. In many cities and towns, DAR chapter secretaries sent the minutes of meetings and, just as often, descriptions of teas and banquets to the society editors of their local newspapers, who usually published them. A Burlington editor grumbled in 1944 or 1945 that "Every organization in the world, from the American Legion and the Daughters of the American Revolution to the WeWill-Gather-at-the-River Society, is trying to chisel the newspapers for as much free publicity as possible. ... Most of the material is of some worth, but more so to the particular agency seeking its publication than to the general public." "Thinking Out Loud," Burlington Hawkeye Gazette, n.d., clipping, Iowa Society DAR Scrapbook (Historian's Book), vol. 4, 1944-1945, box 2, DAR Collection. 
after the mid-1920s, when the DAR's red-baiting of peace activists and reformers began to make it controversial. In 1939 editorialists nationwide condemned the DAR for banning the world renowned opera singer Marian Anderson, an African American, from singing in its Washington auditorium. Four years later, the local newspaper in Leon, Iowa, still printed in its society pages the names of Leon women admitted to the DAR. ${ }^{71}$

To the Iowa town matron, the DAR also offered opportunities to experience "society" in the East, commonly held in high cultural esteem by elites of the American periphery. The DAR's annual Continental Congress in Washington, with its prominent speakers (usually including the president of the United States after 1910) and its glittering receptions and teas, was a social event of national magnitude. Associated Press dispatches covering the event appeared in the smallest, most local newspapers. Going to Washington as delegates gave Iowa townswomen the opportunity to socialize with the wives of national political leaders and top military officers, and then to see their names and pictures in their hometown newspapers.

Iowa DAR members' eagerness to interact with eastern elites sometimes soured into resentment. Northeastern and Washingtonbased women (usually the wives of congressmen and other government officials) dominated the national leadership during the DAR's first forty years. Harriet Lake's 1938 eulogy for Sophia Hyndshaw Bushnell, a national DAR leader from Council Bluffs, captures these regional tensions. When Bushnell, married to a local businessman, was elected a DAR Vice-President General in 1906, she was the first national DAR leader from Iowa "so elected without the benefit of Official Position in Washington." Lake wrote that with her "exquisite" taste in clothes and other personal refinements, Bushnell overcame the provincialism of eastern women. She "won the admiration and the friendship of women of the East and the South, and convinced them that fine women lived in this mysterious western country. ${ }^{172}$

71. "Join DAR Society," Leon Journal Reporter, 14 January 1943, clipping, Iowa Society DAR Scrapbook (Historian's Book), vol. 3, 1942-1943, DAR Collection. 72. "Services for Mrs. Bushnell," n.d. [June 1938], otherwise unidentified clipping; Harriet Lake, tribute to Mrs. Drayton Bushnell, 1938-1939, Minutes of 
Despite these strains, the DAR held many attractions for the socially ambitious women of the American interior. In Iowa and elsewhere, some women joined the DAR simply because their relatives, friends, and people they admired did. Belonging to the DAR gave them opportunities to interact with other local and national elites.

By belonging to the Daughters of the American Revolution, women in Iowa cities and towns, like women all over the country, negotiated the complexities of regional and national identity. Between the end of Reconstruction and the 1920s, the United States settled gradually and uneasily into its new incarnation as one unified nation. The DAR replicated this process. Confronting the legacies of the Civil War and westward expansion head-on, DAR members transformed the symbols of northern triumph into the glue that they hoped would bind together a people accustomed to identifying with their localities and states (or, until recently, to wandering west) into one singular political society: a nation. At every DAR chapter meeting, from Des Moines to Ida Grove, from Maine to Arizona, DAR members followed the same ritual. They faced a small American flag on a stand, placed their right hands over their hearts, and pledged their allegiance to "one nation, indivisible." Just as they attempted to Americanize newer immigrants, DAR members attempted to Americanize themselves and each other through their promotion of a flexible nationalism that accommodated and coopted regional identities everywhere. These attempts never succeeded completely: DAR members waged frequent debates about how "national" - meaning how centralized - the National Society of the Daughters of the American Revolution should be. Yet its accommodation of regional diversity ensured that the DAR's nationalist message would be spread by women in every region and state. By constructing a history of the nation's origins that encompassed regional and local history, and by encouraging the pursuit of many other nonhistorical projects on a national basis, the DAR overcame potential barriers to its growth west of the Appalachians. Thus the National Society of the Daughters of the Amer-

the Fortieth Conference, 170-171, clipping, State Chaplain's Record/Necrology Rolls Scrapbook, 1903-1948, vol. 1, box 2, DAR Collection. 
ican Revolution ensured that it would become a truly national society. This helps explain why so many women living on Iowa's rolling prairies, more than a thousand miles from Lexington Green, identified as Daughters of the American Revolution. 
Copyright of Annals of Iowa is the property of State of Iowa, by \& through the State Historical Society of Iowa and its content may not be copied or emailed to multiple sites or posted to a listserv without the copyright holder's express written permission. However, users may print, download, or email articles for individual use. 